\title{
Ekstrak Etanol Biji Pinang Muda (Areca catechu L) Meningkatkan Apoptosis pada Sel Testikular Mencit (Mus musculus L)
}

\author{
The Increas of Apoptosis of mice (Mus musculus L) Testicular Cells because of young Betel \\ Nut (Areca catechu L.) Ethanol Exctract
}

\author{
Sony Heru Sumarsono ${ }^{1 *}$, Eka Pasana Pujowati ${ }^{1}$, Indra Wibowo ${ }^{1}$, Ayda T Yusuf ${ }^{1}$ \\ ${ }^{1}$ Sekolah Ilmu dan Teknologi Hayati, Institut Teknologi Bandung, Bandung \\ E-mail: sonyheru@sith.itb.ac.id *Penulis korespondensi
}

\begin{abstract}
Betel nut (Areca catechu L.) has been known to containing natural substances that have a potential role in causing apoptosis of the germ cells during spermatogenesis. Our research research results showed the change of testicular germ cells on adult mice after treated with betelnut ethanol extract. The way betel nut exctract prepared was by masseration, dilution, evaporation, drying and then diluted into 1\% Arabian gum to match the doses. Male Swiss Webster mice ( 8 weeks old, $30-35 \mathrm{~g}$ weight) were divided into five groups; (1)K=Control group, (2) $\mathrm{KP}=$ Solvent control group (1\% Arabian gum), (3). P1=Treated group 1 (dose $300 \mathrm{mg} / \mathrm{kg}$ body weight (BW) of betel nut extract), (4). P2=Treated group 2 (dose $500 \mathrm{mg} / \mathrm{kg} \mathrm{BW}$ of betel nut extract), (5). P3=Treated group 3 (dose $700 \mathrm{mg} / \mathrm{kg} \mathrm{BW}$ of betel nut extract). The mice were weighted before and after treatment. Treatment was carried out by gavaging the mice with the extract daily for 17 days. The mice were then sacrificed on day 18 by cervical dislocation. Testis were collected, weighted, photographed, then fixed for histological slides preparation, and TUNEL (terminal deoxynucleotidyl transferase dUTP nick end labeling) assay. The results showed that there were: (1) decreasing of testis relative weight, especially in P3, (2) the size of the testis were smaller in the treated group, (3) there were some difference structures of testicular tissuesespecially P2 and P3 groups such as: (a) lowertotal number of the seminiferus tubules/testis, (b) diameter of the seminiferous tubules were smaller, (c) increasing space between the seminiferous tubules, and(d) hypospermatogenesis showed by a decline of testicular cells total number, (e) increasing apoptosis of testicular cells. We conclude that ethanol extracts of areca nutis increase the apoptotic cells and have potential as male antifertility agent.
\end{abstract}

Keywords: apoptosis, areca nut, ethanol extract, Areca catechu, testis

\section{Abstrak}

Biji pinang memiliki potensi sebagai bahan antifertilitas dan diduga dapat menginduksi apoptosis sel-sel spermatogenik. Penelitian ini membahas tentang perubahan jaringan testikular mencit akibat pemberian ekstrak etanol biji pinang muda. Ekstrak etanol biji pinang muda disiapkan dengan maserasi, penjemuran, perendaman dan evaporasi hingga diperoleh serbuk ekstrak etanol yang kemudian dilarutkan dalam larutan Gum Arab 1\% sesuai dosis. Mencit jantan galur Swiss Webster (umur8 minggu, berat 30-35 gram) dibagi dalam 5 kelompok perlakuan: (1) $\mathrm{K}=$ Kontrol, (2) KP = Kontrol pelarut (Gum Arab 1\%), (3) P1 = Perlakukan 1 (dosis $300 \mathrm{mg} / \mathrm{kg}$ berat badan (bb)), (4) P2= Perlakuan 2 (dosis $500 \mathrm{mg} / \mathrm{kg} \mathrm{bb),} \mathrm{dan} \mathrm{(5)}$ P3=Perlakuan 3 (dosis $700 \mathrm{mg} / \mathrm{kg}$ bb), diberikan secara oral (gavage) selama 17 hari. Mencit ditimbang sebelum perlakuan dan setelah perlakuan. Mencit dibunuh pada hari ke 18 dengan dislokasi leher, testis diisolasi, ditimbang dan difoto untuk mengetahui penambahan berat dan ukuran. Preparat histologi sayatan testis disiapkan dengan pewarnaan HE dan TUNEL (terminal deoxynucleotidyl transferase dUTP nick end labeling) assay untuk mengamati apoptosis. Hasil pengamatan menunjukkan terjadi (1) penurunan berat relatif testis kelompok P3, (2) ukuran testis relatif lebih kecil pada kelompok perlakuan, (3) perbedaan struktur jaringan testis pada kelompok P2 dan P3, al: (a) jumlah tubulus seminiferus lebih sedikit, (b) diameter tubulus seminiferus lebih kecil, (c) jarak antar tubulus seminiferus lebih renggang, (d) penurunan jumlah sel testikular, dan (e) peningkatan jumlah sel yang mengalami apoptosis. 
Sumarsono dkk.,

\section{Ekstrak etanol biji pinang menyebabkan peningkatan apoptosis dan memiliki potensi sebagai agen alami antifertilitas pria.}

Kata kunci: apoptosis, biji pinang, ekstrak etanol, Areca catechu, testis

Diterima: 26 November 2017, disetujui: 15 Desember 2017

\section{Pendahuluan}

Penggunaan bahan alam sebagai alternatif kontrasepsi memberikan keuntungan. Selain murah dan mudah diperoleh, dapat memenuhi persyaratan kesehatan yaitu dapat menurunkan kualitas dan daya fertilitas spermatozoa tanpa efek samping pada perilaku seksual, dan dapat pulih kembali dalam jangka waktu singkat. Salah satu tanaman yang telah diteliti mampu menurunkan kualitas dan kuantitas sperma yaitu biji pinang muda (Areca catechu $\mathrm{L}$ ).

Biji pinang dikenal memiliki potensi sebagai antifertilitas karena kandungan senyawa utama antara lain: arekolin, arecaidine, guvacoline, dan guavacine. Alkaloid arekolin yang terkandung di dalam biji pinang menjadi penyebab utama berbagai efek biologis di dalam tubuh (Garg dkk., 2014). Ekstrak biji pinang, maupun arekolin telah diketahui dapat menyebabkan disfungsi sistem reproduksi dan sperma secara in vivo dan in vitro pada tikus, mencit dan manusia, seperti terjadi penurunan jumlah sperma, sel Sertoli, sel Leydig dan motilitas sperma, serta menyebabkan abnormalitas pada bentuk kepala sperma (Kiong dkk., 2006, Er dkk., 2006; Aulanni'am dkk., 2007; Wu dkk., 2010; Yuan dkk., 2012, dkk., 2014).

Pemberian ekstrak biji pinang maupun arekolin dapat mempengaruhi beberapa proses biologis di dalam tubuh seperti represi gen yang berperan dalam detoksifikasi, mengganggu stabilitas struktur kromosom, memicu pembentukan arecoline-DNA adduct dan gangguan sistem perbaikan DNA sehingga mengakibatkan kerusakan DNA yang berakibat pada kematian sel apoptosis (Nery, 1971; Chiang dkk., 2007). Lee dkk., 2006, dan Aulanni'am dkk., 2007 melaporkan bahwa Arekolin dapat memicu apoptosis pada sel-sel somatik di dalam tubuh. Penelitian pengaruh ekstrak biji pinang maupun arekolin pada apoptosis sel testikular belum pernah dilaporkan, meskipun diketahui bahwa apoptosis juga merupakan parameter penting pada kasus infertilitas (Wang dkk., 2003). Sinha dan Rao, (1985) melaporkan bahwa arekolin juga bersifat mutagenik terhadap sel germinal pada mencit.

Oleh karena itu, penelitian mengenai pengaruh biji pinang muda terhadap perubahan struktur jaringan testis dan apoptosis pada sel testikular perlu dilakukan. Studi mengenai apoptosis dapat dijadikan indikasi infertilitas untuk mengetahui lebih lanjut potensi biji pinang muda sebagai agen antifertilitas.

\section{Metode Penelitian}

Pembuatan ekstrak etanol biji pinang muda dilakukan dengan metode maserasi menggunakan etanol 96\%. Biji pinang muda (masih hijau) diiris, dikering-anginkan, dan dihaluskan menjadi simplisia biji pinang muda berbentuk serbuk. Simplisia direndam di dalam tabung maserator menggunakan etanol $96 \%$ dengan perbandingan 1:2 (1,5 kg simplisia:3 liter etanol 96\%) selama 24 jam. Kemudian larutan dievaporasi menggunakan Rotary Vacum Evaporator (Rotavapor) dengan suhu $50^{\circ} \mathrm{C}$ hingga didapatkan ekstrak yang kental dan pekat. Selanjutnya ekstrak kental hasil diuapkan sampai kering (berbentuk padat berwarna cokelat gelap) menggunakan cawan penangas di atas waterbath dengan suhu $55^{\circ} \mathrm{C}-60^{\circ} \mathrm{C}$. Ekstrak kering hasil penguapan kemudian dihaluskan sehingga berbentuk serbuk, dan dilarutkan dalam Gum Arab 1\% sehingga diperoleh dosis 300 $\mathrm{mg} / \mathrm{kg} \mathrm{bb}, 500 \mathrm{mg} / \mathrm{kg} \mathrm{bb}$, dan $700 \mathrm{mg} / \mathrm{kg} \mathrm{bb}$. Penentuan dosis mengacu pada penelitian sebelumnya menggunakan mencit betina (belum dipublikasi).

Mencit jantan (Mus musculus) galur Swiss Webster berumur 8 minggu dengan berat berkisar 30-34 gram diperoleh dari unit pemeliharaan hewan Sekolah Ilmu dan Teknologi Hayati ITB. Selama pemeliharaan, makanan berupa pelet (CP551 - Charoen 
Phokphand Indonesia) dan air minum disediakan secara ad libitum.

Sebanyak 25 mencit jantan dibagi menjadi 5 kelompok yaitu (1) kelompok kontrol negatif/K- (akuades), (2) kontrol pelarut/KP (larutan gum arab 1\%), (3) Perlakuan I/P1 (ektrak biji pinang dengan dosis $300 \mathrm{mg} / \mathrm{kg} \mathrm{BB}$ ), (4) Perlakuan II/P2 (ektrak biji pinang dengan dosis $500 \mathrm{mg} / \mathrm{kg} \mathrm{BB}$ ), dan (5) Perlakuan III/P3 (ektrak biji pinang dengan dosis $700 \mathrm{mg} / \mathrm{kg} \mathrm{BB}$ ). Mencit pada setiap kelompok masing-masing diberi perlakuan secara oral (gavage) menggunakan spuit injeksi volume $1 \mathrm{~mL}$ dan jarum gavage ukuran 20 gauge selama 17 hari. Pada hari ke-18 mencit dibunuh secara dislokasi leher dan dibedah. Testis ditimbang dan difiksasi dalam larutan para formaldehyde $4 \%$ untuk pembuatan preparat histologi guna pengamatan struktur jaringan testis dan pengamatan apoptosis dengan TUNEL assay.

Berat badan awal ditimbang pada hari pertama perlakuan dan berat badan akhir ditimbang pada hari ke-18. Kemudian ditentukan selisih berat badan dan ditentukan persentase peningkatan berat badan dengan rumus:

Persentase Perubahan Berat Badan $(\%)=$

$\frac{\text { Berat Badan Akhĩ-Berat Badan Awal }}{\text { Berat Badan Akhĩr }} x 100$

Testis ditimbang menggunakan neraca analitik dan data yang diperoleh digunakan untuk mengukur berat relatif testis sebagai berikut:

Berat Relatif Testis $(\mathrm{gr} / 10$ gr BB) $=$

$\frac{\text { Berat Testis Absolut }}{\text { Berat Badan Akhir }}$ x10

Sementara itu, perbedaan ukuran testis ditampilkan dalam bentuk foto.

Pengamatan struktur jaringan testis dilakukan menggunakan metode histologi paraffin embedding dengan pewarnaan hematoxylin-eosin. Pada pengamatan struktur jaringan testis dilakukan kuantifikasi data berupa data jumlah tubulus seminiferus dan diameter tubulus seminiferus. Data jumlah tubulus seminiferus diperoleh dari rata-rata jumlah tubulus seminiferus pada lima testis mencit per kelompok perlakuan. Data diameter tubulus diperoleh dari rata-rata 10 diameter tubulus seminiferus pada setiap kelompok perlakuan.
Metode untuk mendeteksi sel yang mengalami apoptosis dapat berdasarkan pada karakteristik apoptosis yang salah satunya adalah terjadinya fragmentasi DNA. Metode yang digunakan yaitu metode TUNEL (Terminal deoxynucleotidyl Transferase-mediated dUTP Nick End Labeling) menggunakan In Situ Cell Death Detection Kit TMR red 1 kit for 50 tests (12156792910, Roche). Metode TUNEL dilakukan pada sayatan histologis testis.

Hasil pengamatan dianalisis menggunakan SPSS 16 dengan signifikansi $\mathrm{p}<0,05$. Analisis data dimulai dengan uji normalitas Kormologor Smirnov. Data yang tidak terdistribusi normal diuji menggunakan Uji Kruskal-Wallis, dilanjutkan uji Mann-Whitney. Data yang terdistribusi normal, dilanjutkan dengan uji homogenitas melalui uji parametrik Oneway ANOVA. Untuk mengetahui perbedaan antar kelompok dilanjutkan dengan uji Post Hoc. Data yang homogen dilanjutkan dengan uji Tukey atau Duncen sedangkan data yang tidak homogen dilanjutkan dengan uji Games Howells.

\section{Hasil dan Pembahasan}

Hasil pengukuran menunjukkan bahwa semua kelompok perlakuan mengalami peningkatan berat badan setelah diberi ekstrak biji pinang. Hal ini membuktikan bahwa ekstrak biji pinang yang diberikan tidak bersifat toksik dan tidak berbahaya bagi tubuh mencit.

Data pada Tabel 1 menunjukkan bahwa persen penambahan berat badan mencit pada kelompok P1dan P2 setelah 17 hari perlakuan lebih rendah dibandingkan dengan kontrol. Meskipun belum diketahui mekanismenya, namun ekstrak biji pinang pada dosis 300 $\mathrm{mg} / \mathrm{kgBB}$ dan $500 \mathrm{mg} / \mathrm{kgBB}$ memiliki potensi dalam mempertahankan berat badan melalui penurunan nafsu makan sehingga peningkatan berat badan dapat diperlambat. Hasil yang serupa dilaporkan Strickland dan Duffield (1997) yang menyebutkan bahwa ekstrak biji pinang dapat memperlambat peningkatan berat badan dan indeks massa tubuh. Hasil ini menunjukkan bahwa ekstrak etanol biji pinang muda bisa dimanfaatkan untuk mempertahankan berat badan selama kurun waktu tertentu. 
Hasil pengukuran menunjukkan bahwa berat relatif testis pada kelompok P3 lebih rendah secara signifikan dibanding kontrol (Gambar 1). Sementara itu ukuran testis pada kelompok P2 dan P3 juga tampak lebih kecil dibanding kontrol dan kelompok perlakuan lainnya (Gambar 2).

Berdasarkan hasil tersebut dapat diketahui bahwa pemberian ekstrak biji pinang dapat menyebabkan terhambatnya penambahan berat dan ukuran testis. Berat testis adalah indikator umum dari kesehatan testis secara keseluruhan dan merupakan indikator efektif secara tidak langsung yang mencerminkan adanya perubahan dalam retensi cairan tubulus seminiferus atau perubahan jumlah sel germinal (Creasy dkk., 2002). Elkis dkk., (2013) menyatakan bahwa berat testis merupakan salah satu indikator penting kesehatan testis secara keseluruhan dan mencerminkan perubahan jumlah sel-sel germinal.

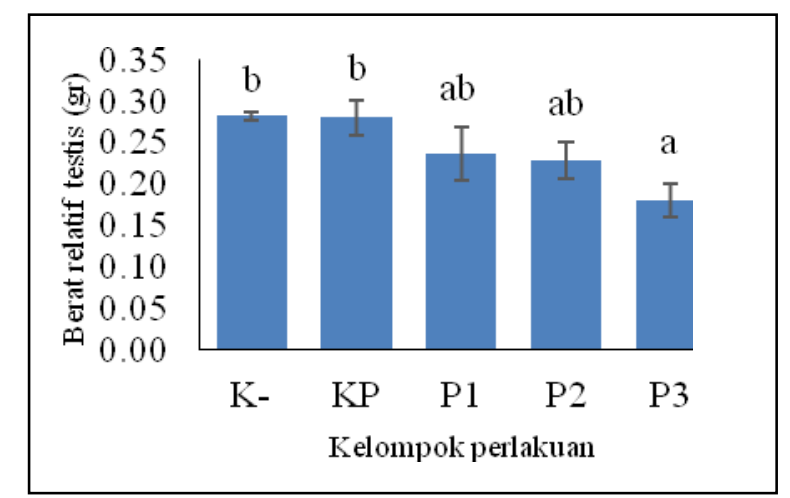

Gambar 1. Berat relatif Testis setelah 17 hari perlakuan dengan ekstrak etanol biji pinang muda. Simbol yang berbeda menunjukkan beda nyata $(\mathrm{p}<0,05)$.

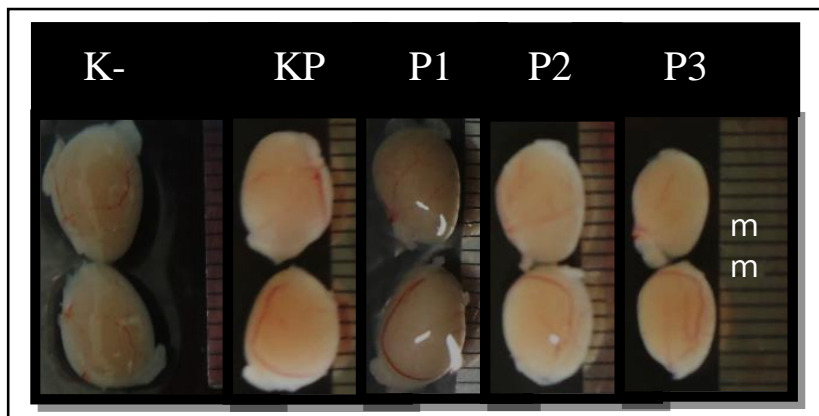

Gambar 2. Testis mencit setelah 17 hari perlakuan dengan ekstrak etanol biji pinang muda.Grid pada masing masing foto menunjukkan millimeter.

Tabel 1. Berat badan mencit pada awal dan akhir percobaan dan penambahan berat badan mencit setelah pemberian ekstrak biji pinang selama 17 hari perlakuan. $(\mathrm{BBAw}=$ Berat badan Awal, BBAk= Berat Badan Akhir, $\mathrm{PB}=$ Penambahan Berat) .

\begin{tabular}{lccccc}
\hline Parameter & \multicolumn{2}{c}{ Kontrol } & \multicolumn{3}{c}{$\begin{array}{c}\text { Ekstrak Etanol Biji Pinang } \\
\text { (Areca catechu L.) }\end{array}$} \\
\cline { 2 - 6 } & $\begin{array}{c}\text { Tanpa } \\
\text { Pelarut } \\
\text { (K-) }\end{array}$ & $\begin{array}{c}\text { Pelarut } \\
\text { (KP) }\end{array}$ & $\begin{array}{c}\text { Dosis 300 } \\
\text { mg/kgBB } \\
(\mathbf{P 1 )}\end{array}$ & $\begin{array}{c}\text { Dosis 500 } \\
\mathbf{~ m g / k g B B ~} \\
(\mathbf{P 2})\end{array}$ & $\begin{array}{c}\text { Dosis 700 } \\
\text { mg/kgBB } \\
(\mathbf{P 3})\end{array}$ \\
\hline BBAw (g) & $32,48 \pm 1,60$ & $33,18 \pm 0,19$ & $33,63 \pm 0,52$ & $32,20 \pm 2,33$ & $31,43 \pm 1,29$ \\
BBAk(g) & $37,58 \pm 2,32$ & $37,72 \pm 0,94$ & $35,92 \pm 0,58$ & $34,26 \pm 2,51$ & $35,42 \pm 2,22$ \\
PB (\%) & $13,51 \pm 1,55$ & $12,01 \pm 2,14$ & $\mathbf{6 , 3 7} \pm \mathbf{1 , 4 3 *}$ & $\mathbf{6 , 0 0 \pm 1 , 5 4 *}$ & $11,13 \pm 3,79$ \\
\hline
\end{tabular}

Ket : * menunjukkan signifikansi ( $\mathrm{p}<0.05)$ dibandingkan dengan kontrol tanpa pelarut. 
Beberapa parameter yang diamati pada pengamatan struktur jaringan testis antara lain jarak intertubular, jumlah tubulus seminiferus, diameter tubulus seminiferus, dan hypospermatogenesis. Pada Gambar 3 dapat diamati bahwa terdapat peningkatan jarak intertubular sehingga jarak tubulus seminiferus lebih renggang dibandingkan dengan kelompok kontrol.Peningkatan jarak intertubular tersebut berkaitan dengan penurunan jumlah tubulus seminiferus yang juga teramati. Hasil kuantifikasi data yang disajikan dalam Tabel 2 menunjukkan bahwa pada kelompok P2 dan P3 jumlah tubulus seminiferus lebih rendah secara signifikan dibandingkan dengan kontrol. Jarak intertubular terbukti lebih renggang/lebar jika dibandingkan dengan jumlah tubulus seminiferus pada kelompok kontrol (Gambar 3). Peningkatan jarak intertubular dan penurunan jumlah tubulus setelah pemberian ekstrak biji pinang disebabkan oleh edema limfatik dan/atau edema interstitial. Menurut Lirdi dkk., (2008), edema ini merupakan konsekuensi langsung dari gangguan lapisan endotel, yang memungkinkan cairan dari darah mengalir ke daerah interstitium. Peningkatan jarak intertubular ini juga diduga memengaruhi efektifitas distribusi hormon testosteron yang dihasilkan oleh sel Leydig pada daerah interstisial menuju sel Sertoli yang berada di dalam tubulus seminiferus. Diameter tubulus seminiferus pada P2 dan P3 teramati lebih kecil dibandingkan dengan diameter tubulus seminiferus pada kelompok kontrol. Penurunan diamater tubulus seminiferus tersebut disebut sebagai terjadi atrofi tubulus seminiferous (Creasy dkk., 2002).

Tabel 2.Jumlah tubulus seminiferus dan diameter tubulus seminiferus testis mencit setelah pemberian ekstrak etanol biji pinang muda. (TS=Tubulus Seminiferus)

\begin{tabular}{|c|c|c|c|c|c|}
\hline \multirow[t]{2}{*}{ Parameter } & \multicolumn{2}{|c|}{ Kontrol } & \multicolumn{3}{|c|}{$\begin{array}{c}\text { Ekstrak Etanol Biji Pinang Muda } \\
(\text { Areca catechu L.) }\end{array}$} \\
\hline & $\begin{array}{c}\text { Tanpa } \\
\text { Pelarut } \\
\text { (K-) }\end{array}$ & $\begin{array}{c}\text { Pelarut } \\
\text { (KP) }\end{array}$ & $\begin{array}{c}\text { Dosis 300 } \\
\text { mg/kgBB } \\
\text { (P1) }\end{array}$ & $\begin{array}{c}\text { Dosis 500 } \\
\text { mg/kgBB } \\
\text { (P2) }\end{array}$ & $\begin{array}{c}\text { Dosis 700 } \\
\text { mg/kgBB } \\
\text { (P3) }\end{array}$ \\
\hline Jumlah TS/Testis & $268 \pm 7,51$ & $273 \pm 3,61$ & $254 \pm 30,32$ & $214 \pm 14,73^{*}$ & $193 \pm 5,86^{*}$ \\
\hline Diameter TS $(\mu \mathrm{m})$ & $166,2 \pm 4,72$ & $171,5 \pm 10,79 *$ & $167,6 \pm 13,62$ & $135,8 \pm 11,86^{*}$ & $118,6 \pm 14,41^{*}$ \\
\hline
\end{tabular}

Keterangan: tanda * menunjukkan signifikansi $(\mathrm{p}<0.05)$ dibandingkan dengan kontrol tanpa pelarut.

Gambar 3. Sayatan Melintang Testis Mencit (Mus musculus L) dengan Pewarnaan HE, perbesaran 100x (atas) dan 400x (bawah).

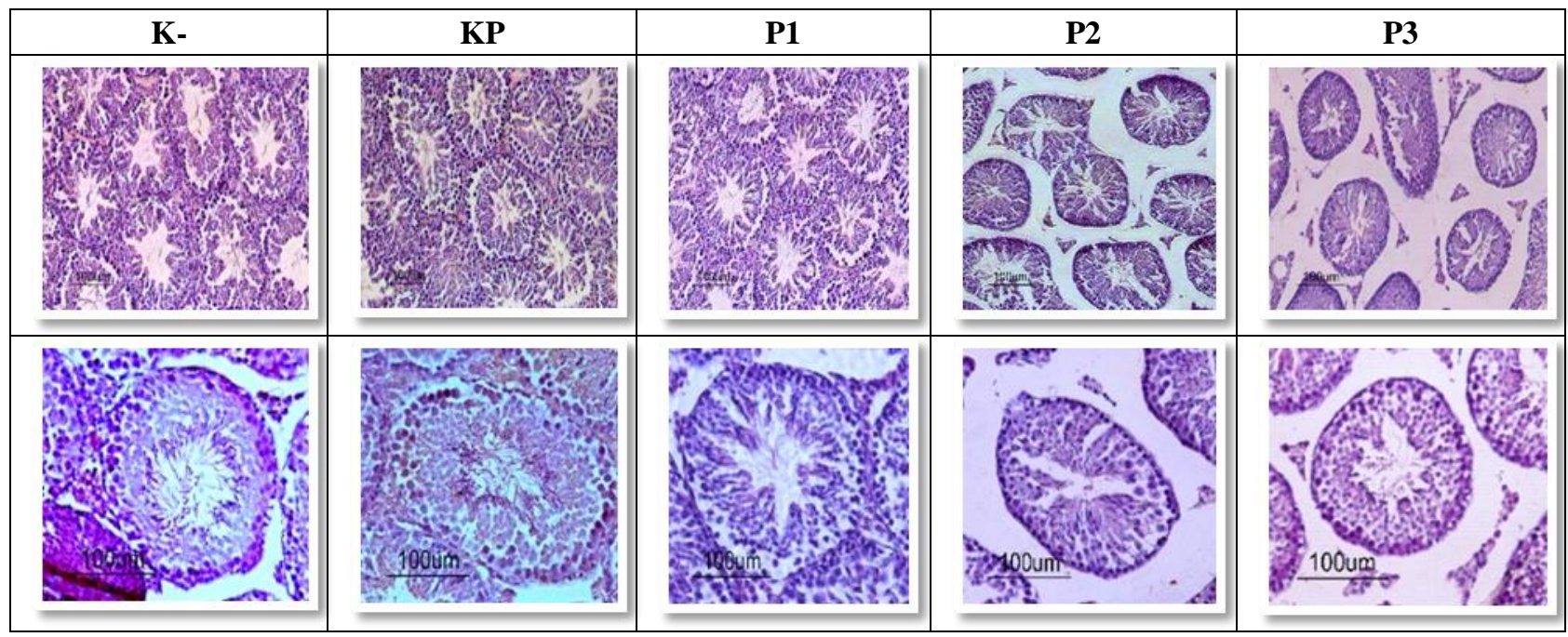

Jarak antar tubulus seminiferus pada kelompok P2 dan P3 lebih renggang jika dibandingkan dengan jarak antar tubulus seminiferus pada kelompok Kontrol. K- = kelompok kontrol, KP = Kelompok Kontrol pelarut, P1 = Kelompok perlakuan dosis $300 \mathrm{mg} / \mathrm{kg}$ bb, $\mathrm{P} 2=$ kelompok perlakuan dosis $500 \mathrm{mg} / \mathrm{kg}$ bb, P3 = kelompok perlakuan $700 \mathrm{mg} / \mathrm{kg}$ bb. Skala $100 \mu \mathrm{m}$. 
Berdasarkan data jumlah tubulus, diameter tubulus, dan data sebelumnya mengenai penurunan berat testis, dapat diasumsikan bahwa terdapat kemungkinan total panjang tubulus seminiferus yang juga berkurang sebagai konsekuensi dari paparan ekstrak biji pinang. Asumsi ini didukung oleh penelitian sebelumnya yang dilakukan oleh Franca dan Russell (1998) yang menyatakan bahwa total panjang tubulus seminiferus terkait dengan tiga parameter struktural yaitu ukuran testis, diameter tubulus dan jumlah tubulus seminiferus. Selain itu, secara kualitatif pada Gambar 3 juga nampak bahwa terdapat hipospermatogenesis yang menunjukkan penurunan jumlah sel spermatogenik pada tubulus seminiferous, yakni kepadatan sel-sel germinal di dalam tubulus seminiferus berbeda antara P2 dan P3 dibandingkan dengan kontrol (data kuantitatif tidak disajikan). Perubahan patologis berupa hipospermatogenesis akibat pemberian ekstrak biji pinang juga diduga terkait dengan gangguan dari fungsi sitoskeleton sel Sertoli, yang menyebabkan hilangnya adhesi sel spermatogenik. Perubahan patologis berupa perubahan diameter tubulus seminiferus, berat testis, penipisan epitel seminiferus disebabkan oleh penurunan fungsi sel Sertoli (Nakai dkk., 2002). Disfungsi sel Sertoli menginduksi penurunan jumlah sel spermatogenik melalui apoptosis (Shaha, 2007; Farrel dkk., 2011).

Pengamatan apoptosis melalui uji TUNEL menunjukkan apoptosis terjadi pada sel di sekitar kompartemen basal tubulus seminiferus yang terdiri dari sel-sel spermatogonial dan sel Sertoli (Gambar 4). Sel-sel yang apoptosis mengalami fragmentasi DNA yang dapat dideteksi dengan TUNEL assay yang ditandai oleh pendaran warna merah di bawah pengamatan mikroskop fluoresensi. Sel yang mengalami kematian apoptosis dapat dideteksi dengan pelabelan inti oleh terminal deoxynucleotidal transferase (Allan dkk., 1987; Print \& Loveland, 2000). Pada kelompok P3 dapat diamati bahwa apoptosis juga terjadi pada sel di daerah interstisial yang terdiri dari berbagai jenis sel terutama sel Leydig.Jumlah sel yang mengalami apoptosis terbukti meningkat secara signifikan pada kelompok P2 dan P3 (Gambar 5).

Ekstrak etanol biji pinang yang mengandung arekolin dapat menyebabkan kerusakan blood testis barier (BTB) sehingga dapat memengaruhi kerusakan pada sel spermatogonia dan sel Sertoli yang terletak di bagian kompartemen basal tubulus seminiferus, dan akhirnya apoptosis sel dapat terjadi. BTB merupakan barrier antara darah dan testis yang dibentuk oleh sel-sel Sertoli dan berfungsi memisahkan kompartemen basal dan adluminal pada tubulus seminiferus. Penelitian Kuo dkk., (2014) menjelaskan bahwa arekolin mampu menginduksi redistribusi ZO-1 yang merupakan salah satu protein penting pada ikatan membran antar sel, melalui peningkatan produksi TNFalpha pada sel Sertoli.Peningkatan TNF-alpha berpengaruh pada aktivasi ERK1/2 MAPKs dan $J N K / P 38$ yang terlibat pada penurunan integritas ikatan membran sel sehingga menyebabkan kerusakan BTB.Hasil penelitian Li dkk., (2006) juga menjelaskan bahwa setelah pemberian arekolin ditemukan adanya peningkatan ekspresi TNF-alpha. TNF-alpha disekresi oleh sel Sertoli dan sel germinal selama spermatogenesis atau sel makrofag dan monosit akibat adanya stimulasi oleh senyawa eksogenik yang telah terbukti dapat mengganggu fungsi BTB. Produksi TNF-alpha, sebuahsitokin pleiotropic dalam testis, merupakan inisiasi dalam induksi apoptosis jalur ekstrinsik sel germinal selamaspermatogenesis (Cheng dan Mruk, 2012).

Apoptosis yang terjadi pada sel spermatogonia juga dapat disebabkan karena peningkatan apoptosis pada sel Sertoli dan sel Leydig yang berperan penting bagi perkembangan sel germinal. Sel Sertoli memproduksi androgen binding protein (ABP) dan nutrisi penting yang dibutuhkan selama spermatogenesis. Gangguan yang terjadi pada sel Sertoli dapat menyebabkan diferensiasi abnormal spermatogonium (Russell dan Griswold, 1993; Hecht, 1995). Sel Leydig memproduksi hormon testosteron yang juga sangat berperan dalam proses spermatogenesis. Pemberian ekstrak biji pinangmuda diduga dapat menyebabkan kerusakan pada sel Sertoli dan sel Leydig sehingga selanjutnya dapat berdampak pada proses spermatogenesis dan menyebabkan apoptosis pada sel testikular mencit, meskipun detil jenis sel yang mengalami apoptosis belum bisa dipastikan, untuk itu perlu dilakukan penelitian lebih lanjut.Selain itu, peningkatan 
apoptosis akibat pemberian ekstrak biji pinang diduga melibatkan adanya pembentukan ROS. Ekstrak biji pinang menginduksi ROS yang berkaitan dengan peningkatan stres oksidatif pada testis (Wu dkk., 2010). Stres oksidatif merupakan sumber potensial yang menyebabkan fragmentasi DNA dan apoptosis sehingga terjadi penurunan jumlah sperma.Arekolin menginduksi produksi ROS yang selanjutnya terlibat dalam penghentian siklus sel, kerusakan DNA, dan menyebabkan kematian sel (Kuo dkk., 2014).

Dari penelitian ini kami menemukan bahwa ekstrak etanol dosis 500 dan $700 \mathrm{mg} / \mathrm{kg}$ bb dapat menyebabkan berat relatif testis lebih rendah dibandingkan kontrol, serta beberapa perbedaan struktur jaringan testis seperti Jumlah tubulus seminiferus lebih sedikit, diameter tubulus seminiferus lebih kecil dengan ruang antar tubulus yang lebih lebar, meningkatnya kerusakan sel-sel testikuler dan meningkatnya apoptosis pada sel-sel jaringan testikuler. Untuk memastikan bahwa kerusakan struktur tersebut berkaitan dengan tingkat fertilitas perlu dilakukan uji kawin mencit jantan apakah masih mampu melakukan kopulasi sekaligus sperma mampu melakukan fertilisasi terhadap sel telur. Jika terbukti positif maka potensi ekstrak etanol biji pinang muda dosis 500 dan $700 \mathrm{mg} / \mathrm{kg}$ bb dalam menurunkan fertilitas mencit jantan dapat dipastikan.

Gambar 4. Pengamatan apoptosis sel spermatogenik pada sayatan melintang tubulus seminiferus dengan uji TUNEL pada kelompok yang diberi perlakuan selama 17 hari, perbesaran 400x.

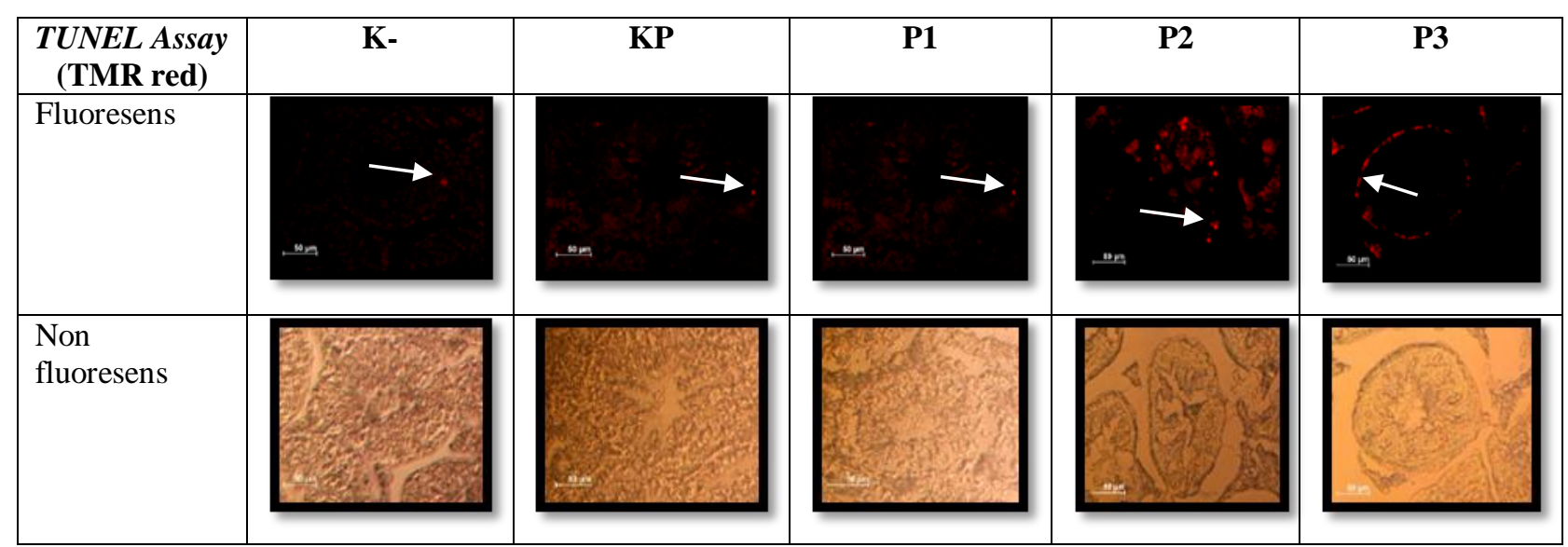

K- = kelompok kontrol, KP = Kelompok Kontrol pelarut, P1 = Kelompok perlakuan dosis 300 mg/kg bb, P2 = kelompok perlakuan dosis $500 \mathrm{mg} / \mathrm{kg} \mathrm{bb}, \mathrm{P} 3=$ kelompok perlakuan $700 \mathrm{mg} / \mathrm{kg} \mathrm{bb}$. Tanda panah berwarna putih pada gambar menunjukkan sel yang mengalami apoptosis. Skala $50 \mu \mathrm{m}$.

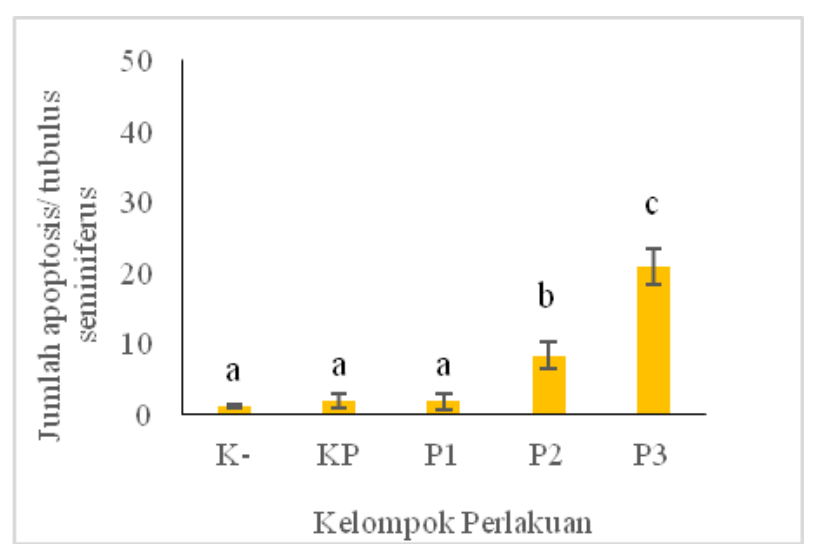

Gambar 5. Jumlah apoptosis sel dalam satu tubulus seminiferus setelah perlakuan selama 17 hari. Simbol yang berbeda menunjukkan perbedaan yang nyata $(\mathrm{p}<0,05)$. 


\section{Simpulan dan Saran}

\section{Simpulan}

Ekstrak etanol biji pinang muda dapat meningkatkan apoptosis pada sel-sel testikuler yang dapat menyebabkan infertilitas.

\section{Saran}

Perlu dilakukan pengamatan lanjutan tentang sel-sel testikuler yang mengalami apoptosis secara spesifik, serta uji kawin mencit jantan untuk memastikan terjadinya infertilitas.

\section{Daftar Pustaka}

Allan, D.J., Harmon, B.V. dan Kerr, J.F.R. 1987. Cell death in spermatogenesis. In Perspectives on Mammalian Cell Death (ed. C. S. Potten), pp. 229-258. London: Oxford University Press.

Aulanni'am, Akmal, M. dan Rosmaidar. 2007: Rattus Norvegicus Antifertility Effect of Aqoueus Extract Betel Nut of Areca catechu: as an Apoptosis Agent on Testis Connective Cells of Rattus Norvegicus. Jurnal Kedokteran Hewan, (23) 3: 179-183.

Chiang, S.L., Jiang, S.S., Wang, Y.J., Chiang, H.C., Chen, P.H., Tu, H.P., Ho, K.Y., Tsai, Y.S., Chang, I. S., dan Ko, Y.C. 2007. Characterization of Arecoline-Induced Effects on Cytotoxicity in Normal Human Gingival Fibroblasts by Global Gene Expression Profiling. Journal of Toxicological Sciences, 100 (1): 66-74.

Cheng, C.Y. dan Mruk, D.D. 2012. The blood-testis barrier and its implications for male contraception. Pharmacol Rev., 64:16-64.

Creasy, D.M. 2002. Pathogenesis of Male Reproductive Toxicity. Journal of Toxicol Pathol, 29: 64-76.

Elkis, Y., Bel, S. dan Goldstein, T.L. 2013. Testosterone Deficiency Accompanied By Testicular And Epididymal Abnormalities In TMF (-/-) Mice. Journal of Mol Cell Endocrinol, 365: 52-63, 2013.

Er, K., Tsai, E.M.,Tsai, L.Y., Ko, Y.C. dan Lee, J.N. 2006. In Vitro Effects of Arecolin on Sperm Motility and Cyclooxygenase-2 Expression. $J$. Toxicological sciences, 31: 75-82.

Farrell, A.W., Halliday, G.M. dan Lyons, J.G. 2011 Chromatin Structure Following UV-Induced DNA Damage, Repair Or Death? Int. J. Mol. Sci. 12: 8063-8085.

Franca, L.R. dan Russell, L.D. 1998. The Testis of Domestic Animals. In: Martinez F, Regadera J. Eds. Male
Reproduction. A Multidisciplinary Overview. Madrid, Spain: Churchill Livingstone.

Garg, A., Chaturvedi, P. dan Gupta, P.C. 2014. A Review of The Systemic Adverse Effects of Areca Nut or Betel Nut. Indian Journal of Medical And Paediatric Oncology, 35 (1): 3 - 9

Kafle, S., Shanbhag, T., Shenoy, S., Amuthan, A., Prabhu, K., Mohan, S., Somayaji S.N. dan Shrestha, J. 2011. Antifertility Effect of Areca catechu in Male Albino Rats., 10 (1): 001-013.

Kiong, E.R., Tsai, E.M., Tsai, L.Y., Ko, Y.C. dan Lee, J.N 2006. In Vitro Effects of Arekolin on Sperm Motility and Cyclooxygenase-2 Expression. $J$. Toxicological Sciences, 31: 75-82.

Kuo, T. M., Luo, S.Y., Chiang, S.L., Lee, C.P., Liu, Y.F., Chang, J.G., Tsai, M.H., dan Ko, Y.C 2014. Arecoline Induces TNF-Alpha Production and Zonula Occludens-1 Redistribution in Mouse Sertoli TM4 Cells. Journal of Biomedical Science, 21: 93.

Lee, P. H., Chang, M.C., Chang, W.H., Wang, T.M., Wang, Y.J., Hahn, L.J., Ho, Y.S., Lin, C.Y. dan Jeng, J.H. 2006. Prolonged Exposure to Arekolin Arrested Human KB Epithelial Cell Growth: Regulatory Mechanisms of Cell Cycle and Apoptosis. Toxicology, 220: 81-89.

Li, M.W., Xia, W., Mruk, D.D., Wang, C.Q., Yan, H.H., Siu, M.K., Lui, W.Y., Lee, W.M. dan Cheng, C.Y. 2006. Tumor necrosis factor \{alpha\} reversibly disrupts the blood-testis barrier and impairs Sertoli-germ cell adhesion in the seminiferous epithelium of adult rat testes. $J$ Endocrinol,190: 313-329.

Lirdi, L.C., Stumpp, T., Cerri, E.S. dan Miraglia, S.M. 2008. Amifostine Protective Effect on Cisplatin-Treated Rat Testis. Anat. Rec., 291:797-808.

Nakai, M., Miller, M.G., Carnes, K. dan Hess, R.A. 2002. Stage-specific effects of the fungicide carbendazim on Sertoli cell microtubules in rat testis. Tissue Cell, 34:73-80.

Nery, R. 1971. The Metabolic Interconversion of Arecoline and Arecoline 1-Oxide in The Rat. Biochem. J., 122: 503-508.

Print, C.G. dan Loveland, K.L. 2000. Germ Cell Suicide: New Insights Into Apoptosis During Spermatogenesis. Bioessays, 22: 423-430.

Russell, L. dan Griswold, M.D. 1993. The Sertoli Cell. Clearwater, FL: Cache River Press.

Shaha, C. 2007. Modulators of Spermatogenic Cell Survival. Soc Reprod Fertil Suppl, 63: 173-86.

Sinha, A. dan Rao, A.R. 1985. Induction of Shape Abnormality and Unscheduled DNA Syntesis by Arecoline in the Germ Cells of Mice. J. Mutat. Res, 158: 189-192. 
Strickland, S.S. dan Duffield, A.E. 1997. Anthropometric status and resting metabolic rate in users of the areca nut and smokers of tobacco in rural Sarawak. Ann Hum Biol., 24 (5): 453-474.

Wang, X., Sharma, R.K., Sikka, S.C., Thomas, A.J. Jr, Falcone, T. dan Agarwal, A. 2003. Oxidative Stress is Associated with Increased Apoptosis Leading to Spermatozoa DNA Damage in Patients with Male Factor Infertility. Fertil Steril, 80: 531 -535.

Wu, P.F., Chiang, T.A., Chen, M.T., Lee, C.P., Chen, P.H., Ko, A.M., Yang, K.J., Chang, P.Y., Ke, D.S. dan Ko, Y. C. 2010. A Characterization of the Antioxidant Enzyme Activity and Reproductive Toxicity in Male Rats Following Sub-Chronic
Exposure to Areca Nut Extracts. Journal Hazard Mater, 178: 541-546.

Yuan, J., Yang, D., Liang, Y., Gao, W., Ren, Z., Zeng, W., Wang, B., Han, J. dan Guo, D. 2012. Alkaloids from Areca (Betel) Nuts and Their Effects on Human Sperm Motility in Vitro. Journal of Food Science, 77 (4): 70-78.

Zeiss, C.J. 2003. The Apoptosis-Necrosis Continuum : Insight From Genetically Altered Mice. Vet. Pathol., 40: 481-495. 